\title{
The Mainland Chinese Managerial Behaviors and Assumptions since the Economic Reform: The Literature Review and Research Proposition
}

\author{
Jose Wong ${ }^{1,2}$, Siew-Huat Kong ${ }^{1}$ \\ ${ }^{1}$ Faculty of Business Administration, University of Macau, Macao, China \\ ${ }^{2}$ Faculty of Hospitality and Tourism Management, Macau University of Science and Technology, Macau, China \\ Email: wcwong@must.edu.mo
}

Received November 15, 2013; revised December 17, 2013; accepted January 12, 2014

Copyright (C) 2014 Jose Wong, Siew-Huat Kong. This is an open access article distributed under the Creative Commons Attribution License, which permits unrestricted use, distribution, and reproduction in any medium, provided the original work is properly cited. In accordance of the Creative Commons Attribution License all Copyrights (C) 2014 are reserved for SCIRP and the owner of the intellectual property Jose Wong, Siew-Huat Kong. All Copyright (C) 2014 are guarded by law and by SCIRP as a guardian.

\begin{abstract}
China is a country that does not stand still. The nation has been on the move since the launch of her reform and opening-up policy in China some 30 years ago. From the infrastructural projects to the look of her people, there is no doubt that great change is taking place. Many entertain the hope that the change this time is for real: China will come out in this process a different country. Some even venture to propose that "China Model" has appeared as a challenge to "Washington Consensus". What about the world of Chinese managers? What changes of Chinese managerial styles did we find in these years? This study will attempt to answer these questions as it tries to ascertain the key driver of this managerial style - the managerial assumptions of the Chinese managers. This analysis will attempt to sketch a Chinese managerial style and propose a set of assumptions that could be shaping this style. The different sources of influence that have come to shape the Chinese managerial assumptions since China launched her economic reform in 1978 would be of particular interest in this adventure. Accordingly, several propositions of Chinese managerial assumptions will be suggested for future research.
\end{abstract}

\section{KEYWORDS}

Chinese Managers; Managerial Style; Assumptions; China Economic Reform

\section{Introduction}

Since the late Chinese paramount leader Deng Xiaoping launched the economic reform project in 1978, Chinese economic growth has never failed to capture the attention of the world. After a rapid pace of development over a period of no less than thirty years, China has now become the second largest economy in the world. Naturally, inquiries of various sorts into Chinese management had also increased in recent years. Our study is consisted of two stages: a portrait of Chinese management style is first of all constructed by identifying its different constituent elements; the investigation then proceeded to look at the underlying assumptions which animated these elements. The purpose of this study is to determine the kind of changes, if any, in the management of Chinese organizations and the source of influence which had been shaping the world of management in that vast country since 1978, which had secluded herself from the rest of the world for a period prior to its opening up and economic reform endeavor.

Accordingly, the paper consists of four main parts. The concept of management styles and assumptions will be introduced in the first part. Some key features of Chinese managers' behaviors which give shape to Chinese managerial style will then be reviewed. In the third part, an investigation of each of the potential underlying assumptions animating Chinese managers will be presented. In the final part, the summary and implications of this finding, especially suggestion for future research, will be discussed. 


\section{Managerial styles}

Managers have different patterns of making decisions and relating to subordinates across different cultures, which give rise to different styles of managing. Muczyk and Steel [1] suggested that managerial styles are important to explore and study because in today's competitive business world, a great deal of enterprises needs to be transformed into quick learning, growth-driven and performance-based with global perspectives. And it is suggested that certain managerial styles are more suited to do so than the others.

Hofstede [2] demonstrated that different nations in the world naturally have different kind of histories and their cultures, which are a product of history, may tend to differ. Managerial style is also subject to the influence of cultural values. Universal managerial styles and management solutions, however, do not exist because different nations have different intellectual or physical resources and hence, they tend to handle different practical problem that may arise in their own respective turf very differently. Yet there is a historical continuity of management within a nation. Different managerial styles between nations are historical rather than geographical. He observed that managerial style, as part of culture, differs among nations but within a nation, it is relatively stable over time. As difference of national managerial styles is thought to be attributed to difference of culture [3], in order to understand better Chinese managerial styles, it is crucial to examine its culture as well. However, it is hard to decipher culture by using overt behaviors alone because situations often may make us act inconsistently with what we believe. For instance, managers often preach to subordinates the virtue of team work but also remind them at the same time that they are all the competitors to become the boss's successor. To discover the elements of culture in organizations, one needs to find the core of their culture-their underlying assumptions [4]. In other words, it is the underlying assumptions that shape and drive managerial behaviors.

\section{Managerial Assumptions}

Schein proposes that when one solution to a problem works repeatedly, it eventually comes to be taken for granted [5]. Every organization has a set of shared basic assumptions that is invented, discovered or developed by a group of people whose experiences worked well to solve certain problems and hence are disseminated to new comers as a recommended way to act. Basic underlying assumptions are something people take for granted, and they are unconscious, nonconfrontable and nondebatable like theories-in-use [6]. Douglas [7] suggested that once a set of basic assumptions have been developed, it is very hard for it to change because we will feel maximally comfortable with others who share the same assumptions with us and will be very uncomfortable with others who have different assumptions. When there is no shared assumption, it is difficult for us to understand in a common way what is going on and even worse, we might misunderstand others and interpret others' behaviors in a wrong way.

Behind every managerial decision or action is a set of managerial assumptions of how the world really works. Some of these key managerial assumptions are pervasive and implicit in most organizations and much of current managerial policies and styles [8]. Such mental models [9] are powerful to determine what managers do. However, shared mental models cannot be discovered easily, but those who do not know their mental models do so at their own risks.

To find out a management style, it is essential for us to know its assumptions [10]. Of special interest to us is the economic reform since 1978 as it is the turning point of Chinese economy from the centrally-planned to the socalled socialist market economy with Chinese characteristics [11], and most importantly, the set of underlying assumptions generated by this gigantic transformation. It has been proposed that even multinational enterprises with managers in different countries tend to display different managerial style, often mirroring that of the host country's, instead of sharing a common managerial style throughout a corporation which may cut across different countries [12]. Based on this argument, as managerial assumptions are animating the managers' behaviors and styles, it could be assumed that there is a common set of managerial assumptions which guide managers' behaviors within a nation.

\section{Key Features of Chinese Managerial Style}

Before we look at the basic assumptions of Chinese managers, the artifacts of Chinese managers will be introduced first in this part. Our findings indicate that, even as the Chinese economy was taking a flight during this historical period, the Chinese managerial style was only evolving quietly but steadily towards a particular pattern, the key features of which will be mentioned as follow.

\subsection{Pursuing Short-Term Profit and Focusing on the Present}

Chinese managers who are more cognizant of both short-term orientation and focusing on present are likely to be more effective in Chinese environment today [13]. In the study of Kong [14], it was observed that Chinese managers tend to demonstrate short-term and present orientation as there is no sign to show them that Chinese society would become more predictable, and people are finding ways to "win the game" before the game is over 
or hijacked. Short-term profit and present orientation is, however, more likely to generate behavior of opportunism and enhancement of self-interestedness. When managers pursue short-term profit, they are very likely to neglect the long-term development of the company. Given a chance, they tend to choose projects that make quick income for the company, so managers might also earn more bonuses. Or, if other companies provide a better salary or a higher position to a manager, he may change their jobs immediately without thinking about the future and long-term development in the new company. In this case, loyalty to the firm is low and ethical consideration is given very little attention. It is also apparent that material benefits are primarily and popularly considered as top most concern among Chinese companies [15]. Furthermore, the material profit and quick success are the key factors when measuring one's achievements [16]. Quantity, rather than quality, is also given higher priority as the former can be packaged easily in neat statistics and figures, something which the Chinese managers are quite enamored with. Though our analysis was confined to those managers in the commercial sector, this very behavior is manifested in equal intensity among managers in the government sector.

\subsection{Flexibility in Principles}

In Liu et al.'s study [17], the structure of Chinese enterprises are likely to mirror that of the hierarchy of a clan culture, which tends to be internally focused but needing flexibility. The bosses are like parents and mentors; they draw the general structure of work and let their subordinates finish it flexibly. Their major concern is getting the job done. As the superiors care less about how people get it done, the Chinese managers are given great flexibility of doing business and following rules and procedures is not a prized tradition. The flexibility of management allows managers to adapt to any uncertain and changing environment and not themselves restricted by any particular regularities and management style [18]. However, there are some disadvantages inherent in this style of management. One of them being that people are often prepared to work in grey areas and business ethics is often not given the consideration that it deserved and the employees tend to care less about the regulations and procedures [12]. And such managerial success is hard to be replicated and transmitted because the procedures of making decision are flexible and consistent regulations and procedures are difficult to be nurtured. For example, when business is successful in one city and the manager wants to replicate the model in another city, it will find it challenging to be transferred elsewhere; hence it is difficult to bring about standardization of practice and policies, assuming they are desirable at all. It should be pointed out that this flexibility in the use of principle is limited mostly to the rank of managers. The managers themselves can be quite bureaucratic and regimented when it comes to interacting with their sub-ordinates and making demands of their juniors.

\subsection{Establishing, Nurturing and Using "Guanxi" to Get Things Done}

When it comes to describing Chinese managerial style, "Guanxi" is frequently cited as an important feature. The behaviors of Chinese managers are often facilitated and at the same time restricted by the network of relationships, and "Guanxi" is certainly one of the key factors Chinese managers pay attention to [19]. Guanxi is a complex interpersonal relationship that maps emotional, material and social obligations of individuals and organizations as they interact [20]. Guanxi has not only influenced business of ethics, but also in the areas of making decision, hiring people and so on. In an empirical study on how managers perceive Guanxi, they suggested that managers regard Guanxi as a key indicator of satisfaction at work and an access in organizations [21]. Guanxi is used in many different areas of managerial decisions of Chinese managers such as hiring employees, making deals with clients, seeking suppliers, finding successors of enterprises and so on [20]. In order to operate a Guanxi network in China, Vanhonacker suggested four steps to establish a Guanxi network with others [22]. They are targeting, scouting, signaling and packaging. In many ways, it would be very challenging for another manager from a rational-legal culture to interact with someone who is deeply in this "Guanxi” culture.

\subsection{Keeping "Face" and "Giving "Face"}

To understand managers in a collectivist society like China, it will be useful to consider how managers perceive their places alongside others, and it takes into the matter of "face" in China [23]. Every class in society has a different "face". It is important for everyone to maintain their "faces", especially in front of the people whom one meets repeatedly. One of the ways to show one's care in organizations is to preserve another's face, particularly the face of managers. In this case, subordinates may have bad feelings about their managers behind their backs, and at the same time, managers may not point out one's mistake in order to keep his face. Understandably, all of these may have some negative effect on the communications between managers and subordinates [24]. For instance, if one manager proposes a bad idea in China, a subordinate will often not want to point out the manager's fault, especially in the presence of others, because people think that managers will lose their faces if their faults were exposed by their own subordinates. At times, the subordinate may even execute an idea that he 
thinks is not a good one and even say it is his fault when the bad idea turns out to be failed. In this manner, truth seems to be the casualty and the ability to independently investigate truth is hugely compromised.

\subsection{Avoiding Conflict Superficially}

When facing conflicts, managers used various strategies to deal with them, such as insisting on his or her point, compromising, avoiding, confronting, passive resistance, finding a third-party and so on [25]. Yan and Sorenson [26] argued that Chinese choice of conflict strategies are not only based on interests or goals of self and other, but also strongly influenced by Confucian values and norms, especially in Chinese family business. As Chinese enterprises pay more attention to maintaining certain relationships, it was found that Chinese managers may experience more cognitive and affective conflict than western countries, and the higher the education level Chinese managers get, the more conflicts they may have [27]. In response to a normative conflict, Tinsley and Weldon [28] argued that Chinese managers tend to show a stronger desire to shame and take it as a moral lesson. Also, they are more likely to express a desire to take revenge in an indirect approach. By contrast, American managers show more direct approach in dealing with conflict, and they are no more likely than Chinese managers to show a strong intention to deliver revenge after conflicts. Conflicts between enterprises are inevitable and this is one of the tasks for managers to manage conflicts. In this case, Wang et al. [29] stated that conflicts with those who have political influence were more likely to be resolved in a serious approach like going to court, while similar problem with those without political influence may resort to mediation or negotiation. But using powerful third parties are common both in the conflicts with or without political influences. In conclusion, Chinese managers prefer a style of avoiding dealing with the conflict headon, because they believe that the direct conflict will hurt the other parties. This demonstrates a greater concern for relationships among people when compared with western countries. Furthermore, Chinese does not resist the social hierarchy; hence they tend to avoid conflict with the other parties who are of higher status, such as seniors and managers in companies or senior class in family, as compared to American [30]. As they avoid handling conflicts directly, however, we should notice that issues do not easily disappear and only a superficial harmony is maintained. Ding [31] argued that Chinese managers regard avoiding conflicts superficially as a proactive approach instead of a passive approach. This would suggest that conflicts should be avoided at all cost in order to maintain a beautiful face. Some Chinese managers like to think that taking a temporary "retreat" occasionally is essential for the purpose of advancing towards their goal and getting to the destination by making a temporary detour at times.

\subsection{Paternalistic Behavior}

The "Li" concept embedded in Confucianism had given rise to the management style of "rule by man". It presupposes that top leaders should cultivate themselves to be bright, of high integrity and good code of conducts, and they will utilize the power in a right way. In the traditional Chinese concept of "rule of man", decisions made by top leaders were not supposed to be questioned. Because of a long period of domination by Confucianism after Han dynasty, "rule by man" has prevailed and developed to become a variant of paternalism which contributed to feudalism in China [32]. In the Mao's era, Strauss [33] suggested that terror and paternalism were two elements the Chinese Communist Party used to control the young PRC in the early 1950s. Fear and terror is used for extending control and paternalism is more like a slogan and used for consolidating control. Instead of using fear and terror to control the society, some scholars [34] argued that state paternalism has now becomes a dominant feature in Chinese business world and the revival of Chinese paternalism after the launch of the economic reform helps create a clearer and more obvious hierarchy in both political and management systems. In conclude, paternalistic Chinese managers' behaviors may similar to traditional paternalism that a manager is playing the role as a father and transfers this family or domestic authority into a working basis in the company [35].

\section{Chinese Managerial Underlying Assumptions}

We have explained in the above some of the key features of Chinese managers today. This part will now look at the potential forces which shaped those very Chinese managerial behaviors. In order to obtain a set of basic assumptions of Chinese managers today, the recent history of two distinct dominant thoughts need to be mentioned. The first one is Maoism and its main campaigns such as working in the countryside; the Great Leap Forward and Cultural Revolution [36,37]. Another one is the thoughts of Deng Xiaoping, especially those on economic reform $[38,39]$. In the post-Deng era, the subsequent leaders such as Jiang Zeming and Hu Jintao were still heavily influenced by the thoughts of Deng's and China continues her development by following the road of Deng's thoughts [40]. For each assumption, the one shaped by the economic reform or Deng's thoughts will be described first, and it will also demonstrate how they animate the key features of Chinese managerial behaviors today. 
Our study indicates that it is the political thoughts, though not all of them were the original thoughts of Deng, and postures that have shaped an entire generation of Chinese managers which are within different kinds of organizations such as SOEs, Joint-Ventures and even foreign-invested enterprises in China. Some of them were from Chinese tradition while some were actually from realm outside of systems that were Chinese but were happened to be used by Deng for his political ends, and were eventually embedded as Chinese managerial assumptions.

\subsection{Pragmatism}

Today's Chinese rapid growth can be traced back to Deng's pragmatic ideas and the economic reform. Pragmatism was, however, forged by John Dewey and celebrated by his followers in the crisis of World War I [41]. Dewey believed that Science and technology are different. Science is a self-conscious and specialized inquiry, while technology is created for practical utilities and enjoyments.

Pragmatism was first introduced into China around the period of the May 4th movement in 1919, which is an unprecedented intellectual ferment [42]. At that time, as John Dewey's student, Hu Shih was one of the first and significant Chinese scholars responsible to introduce the western pragmatism to China. Hu Shih absorbed and used the thought of Pragmatism of his teacher, John Dewey, to transform China, especially in the areas of academic circles, cultural movements and social thoughts [43]. His message was that "Truth is an instrument which changes with different situations, and nature laws are hypotheses tenable only until someone formulates more satisfactory hypotheses [44, p. 553]. Although Pragmatism was disseminated widely and had a shocking effect on Chinese traditional thoughts such as Confucianism, the campaigns against $\mathrm{Hu}$ Shih's pragmatism are raised later, during 1950s. In Mao's era, the thought of Marxism-Leninism-Maoism was advocated as guide for action and no one could challenge it. So pragmatism, as a western philosophy, was only allowed up to a certain limit under Mao’s totalitarianism [44].

Pragmatism maintains that human nature should adapt to the environment; every idea and theory should serve human beings. Deng advocated that people should dare to work and not to be afraid of problems [39]. In the period of economic reform, Deng raised the ideas of "No matter if it is a white cat or a black cat, a cat that can catch rats is a good cat" and "Seeking the truth from facts" which are still shaping to a large extent the Chinese managerial behaviors today [45]. This basic assumption of pragmatism has emboldened the Chinese managers to challenge the traditional culture like Confusion and Taoism, and to show high flexibility in management [46].
Proposition 1: Chinese managers are driven by pragmatism and are prepared to achieve their aims, regardless of methods used.

\subsection{Utilitarianism}

In modern times, as compared to original definition of utilitarianism in western countries, the utilitarianism in China is understood and practiced differently. Firstly, the utilitarianism in China implies searching for quick success and maximum benefits in as short a time as possible, which may not be the same as attaining maximum happiness. Furthermore, the features of utilitarianism are often identified with collectivism as family-oriented collectivistic culture has a strong root in Chinese manager's behavior. This would suggest that the maximum happiness is to be found at the level of family, and not just limited to the individual's alone [47].

The recent development of Chinese utilitarianism can be traced back to Deng's ideas during the period of the economic reform. The core thoughts of the economy reform are to take economic development as a central task, and to solve problems through development [39]. Deng [48] also emphasized that economic development must be at a high speed and stated that slow growth equals stagnation and even retrogression. Many Chinese managers today assumed that decisions in the business world are based on factors such as competitive development, rapid growth, profit making and grabbing opportunities, rather than professional management, as understood in the Western sense [49].

Proposition 2: A Chinese version of utilitarianism is responsible for many of key features of Chinese managerial style like Guanxi, giving “face”, maintaining superficial harmony, pursuing short-term profit and so on.

\subsection{Harmony}

Chen and Ma suggest that harmony is one of the core values of Chinese culture, which is derived principally from Confucianism [50]. As a central principle of Confucianism, the followers of Confucianism were educated to be self-motivated and self-controlled to take the responsibilities for themselves, their families, their king and their country, which finally leads to a harmonious world [51,52]. Another Chinese traditional philosophy, Taoism, also contributed to the notion of harmony, proposing mainly that the relationship between men and nature should be reciprocal and complimentary with each other [53]. Wang and Juslin [54] argued that the Chinese traditionally focuses on two aspects of harmony-harmony at the level of relationships with people, and harmony with nature. The thoughts of Confucian harmony contribute to the former, while the philosophy of Taoism emphasizes on the latter. Nowadays, Chinese managers 
tend to establish a superficial harmonious relationship with people and open conflicts are therefore avoided as far as possible.

Proposition 3: Chinese managers assumed that chaos should be avoided at all costs, but they are only capable of maintaining superficial harmony.

\subsection{Limited and Bounded Trust}

After the Anti-rightist campaign and Cultural Revolution in the years of Mao, it is not difficult to understand why there is such a high level of distrust in the society. Though many from the generation which grew up in Mao's era had become successful economically in the society after the economic reform, the distrust of government and people has not been dispelled [55]. Redding [23] further pointed out that managers prefer to put their trust in their own family, and after that, they would trust their friends and acquaintances to the extent that mutual interest relationship has been developed; face and Guanxi invested in them, with everybody else regarded as outsiders and cannot be trusted. Chinese managers also assume that the nature of human nature is bad, people all care about their self-interest and cannot be trusted [56]. As a result, relationships are mainly built up on self-interest and motivations of workers are also shaped by their own benefits.

Proposition 4: Chinese managers assumed that one has to be very selective as to who can be trusted.

\subsection{Inequality}

The assumption of human inequality can be traced to the Confucian root. The hierarchy is clear and the status in the hierarchy cannot be overstepped [57]. Unequal social status and power distribution are normal and accepted from the ancient China. However, in the years of Mao, the traditional hierarchy of society status was challenged. Maoism suggested that the position and status of people should be determined by their actions, not positions. And Mao's ultimate goal then was to develop an environment of equality so that everyone can share the resources and outcomes. Some of the events like the "Great Leap Forward" and working in the countryside show this thought at work [58]. During the economic reform, Deng [59] then suggested that "let some people become rich first" as this will then drive another segment of the people to become rich. To accomplish the idea of "let some people become rich first”, Deng focused China on developing the economy of coastal regions and set up Special Economic Zones at the beginning of economic reform. To be sure, the inequality of income influences one's social status [60]. However, the mobility through individual effort from low to high hierarchical status is encouraged within the Confucian scheme [61,62].
Proposition 5: Chinese managers assume that individuals come to this world with inherent inequality but that inequality can be altered through one's efforts.

\section{Discussions and Implications}

Table 1 shows the key features of managerial styles and the fundamental assumptions of Chinese managers, which can be considered as a portrait of Chinese managers.

This study is an attempt to explore the key features of Chinese managerial style and the fundamental assumptions of Chinese managers driving those features. We proposed how these assumptions come into being and found that the thoughts of Deng and the economic reform since 1978 are the key factors to form or revive these basic assumptions, and therefore molded the present Chinese managerial style. Specifically, the assumptions of pragmatism, utilitarianism and inequality were forthrightly promulgated, and influenced by Deng's thoughts and the economic reform; the assumptions of harmony and limited trust were from Confucianism and Mao's era, but they had evolved and given different interpretations in Deng's era. However, it has to be acknowledged that a particular managerial style is guided by a set of assumptions; it is difficult to say for sure that a particular style was influenced by one specific assumption alone. A feature may be influenced by two or more assumptions. For instance, the feature of flexibility may mainly be influenced by pragmatism, but it is also partly influenced by utilitarianism.

As the policies in the realm of politics and economics in China after Deng practically followed Deng's thoughts and the road of the economic reform initiated by that dominant leader [63], the managerial assumptions mentioned above, which were formed or revived since the Deng era, have not shown significant change or evolution since his demise. Both the third generation leadership under Jiang Zeming, and the fourth generation leadership under $\mathrm{Hu}$ Jintao still lived in Deng's shadow. This is not to disregard the high level of expectation that remarkable departure from the previous trajectory was expected to occur with the significant advancement of private sector, the influence of foreign firms operating within its border, China joining WTO, the emerging middle class, and so on, but those hopes have up till today remained as just that pious hopes.

This article is to review the current literature related to the Chinese management styles. We found that most of the studies focus on the managerial behaviors and values of Chinese managers; however their behaviors and values may differ greatly, and their mechanism behind is often difficult to interpret. And this article also argues that there is a way for better understanding Chinese managers' mindsets and organizational culture they form through their underlying assumptions. Based on the literature 
Table 1. Proposed chinese managers' styles and assumptions.

\begin{tabular}{|c|c|}
\hline Features of Chinese managerial style & Assumptions of Chinese managers \\
\hline $\begin{array}{ll}\text { - } & \text { Pursuing short-term profit and focusing on present } \\
\text { - } & \text { Flexibility in principles } \\
\text { - } & \text { Guanxi } \\
\text { - } & \text { Keeping "face" and "giving "face" } \\
\text { - } & \text { Avoiding conflict superficially } \\
\text { - } & \text { Paternalistic behavior }\end{array}$ & $\begin{array}{ll}\text { - } & \text { Pragmatism } \\
\text { - } & \text { Utilitarianism } \\
\text { - } & \text { Harmony } \\
\text { - } & \text { Limited and bounded Trust } \\
\text { Inequality }\end{array}$ \\
\hline
\end{tabular}

review, five propositions are concluded and pending to be answered. Finally, future research in this study could address the empirical examination of the Chinese managers in firms. There are plenty of opportunities for further investigation based on the study of managerial assumptions. It is worthy doing the research about managerial assumptions because based on the research results of Chinese managerial assumptions, we can gain a stronger empirical foundation of current managerial assumptions of Chinese managers, and may answer the propositions summarized in the paper, which therefore contribute to better understanding of Chinese managerial behaviors, values, and their business practice.

\section{REFERENCES}

[1] J. P. Muczyk and R. P. Steel, "Leadership Style and the Turnaround Executive,” Business Horizons, Vol. 41, No. 2, 1998, pp. 39-46. http://dx.doi.org/10.1016/S0007-6813(98)90033-7

[2] G. Hofstede, "Asian Management in the 21st Century: APJM,” Asia Pacific Journal of Management, Vol. 24, No. 4, 2007, pp. 411-420. http://dx.doi.org/10.1007/s10490-007-9049-0

[3] B. Bjerke, "Business Leadership and Culture: National Management Styles in the Global Economy,” Edward Elgar Publishing, England, 1999. http://dx.doi.org/10.4337/9781840647600

[4] E. H. Schein, "Three Cultures of Management: The Key to Organizational Learning," MIT Sloan Management Review, Vol. 38, No. 1, 1996, pp. 9-20.

[5] E. H. Schein, "Organizational Culture and Leadership," Jossey-Bass, San Francisco, 2004.

[6] C. Argyris, "Integrating the Individuals and the Organization,” Wiley, New York, 1974.

[7] M. Douglas, "How Institutions Think," Syracuse University Press, New York, 1986.

[8] D. M. McGregor, "The Human Side of Enterprise," McGraw-Hill, New York, 1960.

[9] P. M. Senge, “The Fifth Discipline,” Double-Day, New York, 1990.

[10] E. H. Schein, "Culture as an Environmental Context for Careers,” Journal of Organizational Behavior, Vol. 5, No. 1, 1984, pp. 71-81. http://dx.doi.org/10.1002/job.4030050107

[11] Y. Fan, “The Transfer of Western Management to China:
Context, Content and Constraints," Management Learning, Vol. 29, No. 2, 1998, pp. 201-221. http://dx.doi.org/10.1177/1350507698292005

[12] B. Gerry and P. Chad, "Influence of Culture on Relationship Development Processes in Overseas Chinese/Australian Networks," European Journal of Marketing, Vol. 37, No. 11, 2003, pp. 1548-1574.

[13] J. Li and J. Madsen, "Examining Chinese Managers’ WorkRelated Values and Attitudes," Chinese Management Studies, Vol. 4, No. 1, 2010, pp. 57-76. http://dx.doi.org/10.1108/17506141011033007

[14] S. H. Kong, “The Significance of Organization's Fundamental Assumptions in Change Management-The Case of Mainland Chinese Organizations,” Problems and Perspectives in Management, 2006, pp. 98-110.

[15] X. Dong, “The Impact of China's Millennium Labour Restructuring Program on Firm Performance and Employee Earnings,” The Economics of Transition, Vol. 16, No. 2, 2008, pp. 223-245. http://dx.doi.org/10.1111/j.1468-0351.2008.00322.x

[16] X. Chen, Z. Hu, X. Sun and P. Zhao, "Typology of the Chinese Exporter,” Chinese Management Studies, Vol. 5, No. 3, 2011, pp. 235-255. http://dx.doi.org/10.1108/17506141111163345

[17] A. M. M. Liu, S. B. Zhang and M. Y. Leung, "A Framework for Assessing Organisational Culture of Chinese Construction Enterprises," Engineering, Construction and Architectural Management, Vol. 13, No. 4, 2006, pp. 327342. http://dx.doi.org/10.1108/09699980610680153

[18] A. M. J. Ma and B. Osula, “The Tao of Complex Adaptive Systems (CAS)," Chinese Management Studies, Vol. 5, No. 1, 2011, pp. 94-110. http://dx.doi.org/10.1108/17506141111118480

[19] D. Tan and R. S. Snell, "The Third Eye: Exploring Guan$x i$ and Relational Morality in the Workplace," Journal of Business Ethics, Vol. 41, No. 4, 2002, pp. 361-384. http://dx.doi.org/10.1023/A:1021217027814

[20] S. R. Chatterjee, C. A. L. Pearson and K. Nie, “Interfacing Business Relations with Southern China: An Empirical Study of the Relevance of Guanxi," South Asian Journal of Management, Vol. 13, No. 3, 2006, pp. 59-75.

[21] J. Hong and Y. Engestrom, "Changing Principles of Communication between Chinese Managers and Workers: Confucian Authority Chains and Guanxi as Social Networking," Management Communication Quarterly, Vol. 17, No. 4, 2004, pp. 552-585. http://dx.doi.org/10.1177/0893318903262266

[22] W. R. Vanhonacker, "Guanxi Networks in China,” The 
China Business Review, Vol. 31, No. 3, 2004 pp. 48-53.

[23] G. Redding, “The Spirit of Chinese Capitalism,” de Gruyter, Berlin, 1990.

[24] J. Tang and A. Ward, "The Changing Face of Chinese Management,” Routledge, London, 2003.

[25] W. Yuan, "Conflict Management among American and Chinese Employees in Multinational Organizations in China," Cross Cultural Management, Vol. 17, No. 3, 2010, pp. 299-311.

http://dx.doi.org/10.1108/13527601011068388

[26] J. Yan and R. L. Sorenson, "The Influence of Confucian Ideology on Conflict in Chinese Family Business," International Journal of Cross Cultural Management: CCM, Vol. 4, No. 1, 2004, pp. 5-17. http://dx.doi.org/10.1177/1470595804041521

[27] G. Wang, R. Jing and A. Klossek, “Antecedents and Management of Conflict: Resolution Styles of Chinese Top Managers in Multiple Rounds of Cognitive and Affective Conflict," International Journal of Conflict Management, Vol. 18, No. 1, 2007, pp. 74-97. http://dx.doi.org/10.1108/10444060710759327

[28] C. H. Tinsley and E. Weldon, "Responses to a Normative Conflict among African American and Chinese Managers," International Journal of Cross Cultural Management: CCM, Vol. 3, No. 2, 2003, pp. 183-194.

[29] G. Wang, R. A. Friedman, T. Kim and R. Jing, "Conflict Resolution Strategies of Chinese Private Entrepreneurs: The Role of Political Participation," SSRN Working Paper Series, 2009.

[30] R. Friedman, C. Shu-Cheng and L. A. Liu, "An Expectancy Model of Chinese-American Differences in Conflict-Avoiding,” Journal of International Business Studies, Vol. 37, No. 1, 2006, pp. 76-91.

[31] D. Z. Ding, "Exploring Chinese Conflict Management Styles in Joint Ventures in the People's Republic of China," Management Research News, Vol. 19, No. 9, 1996, p. 43. http://dx.doi.org/10.1108/eb028491

[32] L. Jacobs, G. Guopei and P. Herbig, "Confucian Roots in China: A Force for Today's Business,” Management Decision, Vol. 33, No. 10, 1995, pp. 29-34. http://dx.doi.org/10.1108/00251749510100221

[33] J. C. Strauss, "Paternalist Terror: The Campaign to Suppress Counterrevolutionaries and Regime Consolidation in the People's Republic of China, 1950-1953," Comparative Studies in Society and History, Vol. 44, No. 1, 2002, pp. 80-105. http://dx.doi.org/10.1017/S001041750200004X

[34] P. J. Buckley, J. Clegg and H. Tan, "Reform and Restructuring in a Chinese State-Owned Enterprise: Sinotrans in the 1990s," Management International Review, Vol. 45, No. 2, 2005, pp. 147-172.

[35] J. W. Cox, "Remembrance of Things Past? Change, Development and Paternalism," Journal of Organizational Change Management, Vol. 14, No. 2, 2001, pp. 168-189. http://dx.doi.org/10.1108/09534810110388072

[36] J. Gray and P. Cavendish, "Chinese Communism in Crisis: Maoism and the Cultural Revolution," Praeger, New York, 1968.
[37] A. Nathan, “China’s Transition,” Columbia University Press, New York, 1997.

[38] R. H. Myer, “Chinese Debate on Economic Reform: Can China Create a Socialist Market Economy?” Asian-Pacific Economic Literature, Vol. 9, No. 2, 1995, pp. 55-68.

[39] T. H. Yu, et al., "A Research into the Management Thoughts of Deng Xiaoping," Shanxi People Publishing House, Taiyuan, 1994.

[40] R. Ash and Y. Y. Kueh, "The Chinese Economy under Deng Xiaoping,” Oxford University, England, 1996.

[41] B. Lloyd, "Liberty Philosophy: Nationalism and the Making of American Pragmatism,” Science \& Society, Vol. 73, No. 4, 2009, pp. 498-531. http://dx.doi.org/10.1521/siso.2009.73.4.498

[42] F. Liu, S. Huang and G. F. McLean, "Philosophy and Modernization in China," Council for Research in Values \& Philosophy, People’s Republic of China, 1997.

[43] J. L. Webb, "Dewey: Back to the Future," Journal of Economic Issues, Vol. 36, No. 4, 2002, pp. 981-1004.

[44] L. Chan, "Chinese Communism Versus Pragmatism: The Criticism of $\mathrm{Hu}$ Shih's Philosophy, 1950-1958," The Journal of Asian Studies (Pre-1986), Vol. 27, No. 3, 1968, pp. 551-570.

[45] S. L. Wong, "Chinese Entrepreneurship and Economic Development,” In: B. McCormick and J. Unger, Eds., China after Socialism in the Footsteps of Eastern Europe or East Asia, Sharpe, New York, 1996.

[46] M. Hsu and K. Chiu, “A Comparison between I-Ching's Early Management Decision-Making Model and Western Management Decision-Making Models," Chinese Management Studies, Vol. 2, No. 1, 2008, pp. 52-75.

[47] J. Li, "Family-Oriented Collectivism and Its Effect on Firm Performance: A Comparison between Overseas Chinese and Foreign Firms in China," International Journal of Organizational Analysis, Vol. 8, No. 4, 2000, pp. 364-379. http://dx.doi.org/10.1108/eb028923

[48] X. Deng, "Selected Works of Deng Xiaoping (Volume I)," People’s Publishing House, 1993.

[49] R. Alas and W. Sun, "Organizational Changes in Chinese Companies: A Resource-Based View,” Chinese Management Studies, Vol. 1, No. 4, 2007, pp. 225-242. http://dx.doi.org/10.1108/17506140710828514

[50] G. M. Chen and R. Ma, "Chinese Conflict Management and Resolution US,” Greenwood Publishing Group, 2002.

[51] Y. Fan, “A Classification of Chinese Culture,” Cross Cultural Management: An International Journal, Vol. 7, No. 2, 2000, pp. 3-10. http://dx.doi.org/10.1108/13527600010797057

[52] B. Murphy and R. M. Wang, "An Evaluation of Stakeholder Relationship Marketing in China," Asia Pacific Journal of Marketing and Logistics, Vol. 18, No. 1, 2006, pp. 7-18. http://dx.doi.org/10.1108/13555850610641055

[53] C. Li, "The Confucian Ideal of Harmony," Philosophy East \& West, Vol. 56, No. 4, 2006, pp. 583-603. http://dx.doi.org/10.1353/pew.2006.0055

[54] L. Wang and H. Juslin, "The Impact of Chinese Culture on Corporate Social Responsibility: The Harmony Ap- 
proach,” Journal of Business Ethics, Vol. 88, No. 3, 2009, pp. 433-451.

http://dx.doi.org/10.1007/s10551-009-0306-7

[55] C. K. Pang, D. Roberts and J. Sutton, "Doing Business in China-The Art of War?" International Journal of Contemporary Hospitality Management, Vol. 10, No. 7, 1998, pp. 272-282.

http://dx.doi.org/10.1108/09596119810240889

[56] S. H. Kong, "A Portrait of Chinese Enterprise through the Lens of Organizational Culture,” Asian Academy of Management Journal, Vol. 8, No. 1, 2003, pp. 83-102.

[57] H. Q. Lei, "Modern Management and Confucian Wisdom," Cosmos Books (In Chinese), Hong Kong, 1992.

[58] D. Y. F. Ho, "The Conception of Human Nature in Mao Tse-Tung Thoughts,” In: A. Paranjpe, Ed., Asian Contribution to Psychology, Praeger Publisher, New York, 1988, pp. 53-78.
[59] X. Deng, "Selected Works of Deng Xiaoping (Volume II),” People’s Publishing House, 1994.

[60] J. Chen and B. M. Fleisher, "Regional Income Inequality and Economic Growthin China," Journal of Comparative Economics, Vol. 22, No. 2, 1996, pp. 141-164. http://dx.doi.org/10.1006/jcec.1996.0015

[61] D. J. Munro, “The Conception of Man in Early China,” Stanford University Press, Stanford, 1969.

[62] S. L. Wong, "Emigrant Entrepreneurs: Shanghai Industrialists in Hongkong," Oxford University Press, Hong Kong, 1988.

[63] D. Bachman, "Succession Politics and China’s Future," Journal of International Affairs, Vol. 49, No. 2, 1996, pp. 370-390. 